\title{
STUDI KRITIS ATAS DOMINASI POLITIK DALAM PENULISAN SEJARAH ISLAM MENUJU SEJARAH UTUH DARI PERSPEKTIF THE NEW HISTORY
}

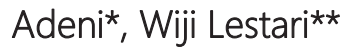 \\ *Fakultas Dakwah dan Komunikasi, UIN Walisongo Semarang, Indonesia \\ **Pascasarjana UIN Syarif Hidayatullah, Jakarta
}

\begin{abstract}
The aim of this article is to criticize the construction of Islamic history which is generally dominated by political history. So far, political power is considered a central point for the civilization of a nation. Islam, as assessed by Harun Nasution (2005), could develop because of political power. Therefore, it is necessary to extract and write Islamic history in its entirety by not categorizing Islamic history based on the period of transfer of political power from one dynasty to another, while forgetting the deepening of the socio-economic aspects, education, culture, art, architecture, interaction patterns of Islamic community life, community livelihoods and so on. Through qualitative research using The New History approach from Robenson (2002), this article confirms that Islamic history is not only about political history, but also includes socio-cultural history that touches all sides of Muslim life.
\end{abstract}

Keywords: Islamic history, political history, The New History.

\section{Abstrak}

Artikel ini bertujuan memberikan kritik terhadap konstruksi sejarah Islam yang umumnya didominasi oleh sejarah politik. Selama ini, kekuasaan politik dianggap sebagai titik sentral bagi peradaban suatu bangsa. Islam, sebagaimana dinilai oleh Harun Nasution (2005), bisa berkembang karena kekuasaan politik. Karena itu, dibutuhkan penggalian dan penulisan sejarah Islam secara utuh dengan tidak mengkategorikan sejarah Islam berdasarkan periode perpindahan kekuasaan politik dari satu dinasti ke dinasti lain, sementara melupakan pendalaman terhadap aspek sosial ekonomi, pendidikan, kebudayaan, seni, arsitektur, pola interaksi dan pola kehidupan masyarakat, mata pencaharian masyarakat, dan sebagainya. Melalui penelitian kualitatif dengan pendekatan The New History dari Robenson (2002), artikel ini menegaskan bahwa sejarah Islam tidak hanya tentang sejarah politik, tetapi juga mencakup sejarah sosial-budaya yang menyentuh segala sisi kehidupan umat Islam.

Kata Kunci: Sejarah Islam, sejarah politik, sejarah sosial, The New History.

\section{PENDAHULUAN}

Ahmad Amin (2011) dalam buku Dhuha al-Islam memulai pembahasannya dengan sebuah kritik terhadap konstruksi sejarah Islam. Baginya, pergantian kekuasaan (daulah) dalam Islam seperti Bani Umayah yang digantikan Bani Abbasiyah perlu dilihat dari sudut pandang sosiologis. Sepertinya yang ia maksudkan adalah keadaan sosial suatu kekuasaan politik tidak bisa dinegasikan oleh kekuasaan baru yang mengambilalih. Dengan kata lain, sejarah sosial tetap berlanjut, meskipun sejarah atau daulat kekuasaan telah sirna.

Kenyataan tersebut di atas tampaknya kurang diapresiasi dalam banyak penulisan sejarah Islam. Sejarah Islam identik dengan sejarah politik (Azra, 1999). Pergantian kekuasaan, politik raja-raja, ekspansi atau penaklukan wilayah selalu mewarnai teks-teks sejarah Islam. Sejarah Islam diwakili oleh sejarah politik suatu dinasti, untuk kemudian ditumbangkan oleh dinasti lain. Dinasti yang sedang berkuasa menafikan keberadaan dinasti sebelumnya. Di sisi lain, sejarah Islam tidak jarang direduksi menjadi sejarah peperangan dan kerajaan-kerajaan sehingga setiap kali

*Correspondance Author: adeni@walisongo.ac.id | wiji.lestari@uinjkt.ac.id

Article History | Submitted: January 8, 2020 | Accepted: January 24, 2020 | Published: January 25,2020

How to Cite (APA $6^{\text {th }}$ Edition style):

Adeni \& Wiji Lestari. (2020). Studi Kritis atas Dominasi Politik dalam Penulisan Sejarah Islam menuju Sejarah 
muncul persoalan keislaman di tengah masyarakat, pencarian solusinya hampir selalu merujuk pada pola pikir struktural-top-down, bahkan politis, padahal ada sudut pandang sosial yang bisa ditawarkan dalam konteks itu (Azra, 2002, pp. 12-20).

Akibat dari format penulisan sejarah yang demikian adalah terpetak-petaknya sejarah Islam dalam batas-batas politik suatu kekuasaan, padahal aspek sosial, seperti pendidikan, sistem ekonomi, seni dan arsitektur, dan lain-lain senantiasa diwarisi dari sebuah dinasti atau kekuasaan yang telah runtuh ke dinasti lainnya. Dalam mukaddimah bukunya, Ibrahim Hasan (1996) dan Jurji Zaidan (200o) menyatakan bahwa sejarah hakiki umat Islam adalah sejarah peradaban dan kebudayaannya, bukan sejarah penaklukan dan peperangan.

Objek sejarah di wilayah menjadi termarjinalkan dengan adanya objek sejarah yang lain, baik dari wilayah itu sendiri atau objek sejarah dari daerah yang menganeksasi daerah tersebut. Sesuatu yang menyebabkan ini terjadi, bisa kepentingan politik dan kepentingan-kepentingan yang lain. Hal ini terjadi misalnya sebagai contoh sederhana, dalam perjalanan sejarah panjang Hijaz (Mekah dan Madinah) (Zaidan, 2000, p. 24). Sejarah kawasan ini seakan hilang dari perkembangan sejarah secara umum dari sejarah Timur Tengah.

Kenyataan sejarah Hijaz yang disebutkan ini pada dasarnya merupakan implikasi dari paradigma penulisan sejarah Islam yang berkembang selama ini. Terdapat sebuah anggapan bahwa politik dan hal-hal kekuasaan merupakan poros atau sumbu sejarah yang menentukan perkembangan seluruh aspek kehidupan yang lain. Paradigma seperti ini sebenarnya mendapat kritikan yang tajam karena beberapa hal, di antaranya: Pertama, karena kehidupan kebudayaan manusia tidak menyangkut politik saja. Kedua, sejarah manusia secara objektif tidak hanya ditentukan oleh politik para penguasa (Haghnavaz, 2013). Terdapat aspek-aspek lain yang menentukan perjalanan sejarah manusia. Karenanya, dibutuhkan suatu pendekatan yang disebut dengan pendekatan The New History atau Total History dalam penulisan sejarah Islam.

Sudut pandang The New History dalam penulisan sejarah Islam berbeda dengan sudut pandang sejarah lama (old history). Terdapat dua guru besar, yaitu Marc Bloch dan Lucien Febvre yang menerbitkan jurnal Annales D'histoire Economique et Sociele, di Perancis pada dekade 1920-an. Dari sini kemudian dikenal mazhab Annales (Huppert, 1982). Jurnal ini mengkritik tajam para sejarawan tradisional. Aspek yang mereka tantang salah satunya adalah dominasi sejarah politik. Mereka berupaya menggantikan sudut pandang sejarah ke arah yang lebih luas dan manusiawi, di mana politik tidak harus selalu mendominasi materi-materi penulisan sejarah. Hannes Swoboda dan Jan Marinus Wiersma (2009) mengatakan bahwa sejarawan dan politisi terkadang saling mendukung dalam membangun sebuah sejarah. Akibatnya memang tidak jarang politik memang lebih mendominasi penulisan sejarah.

Pada dasarnya, istilah The New History muncul dalam periode perkembangan mazhab Annales. Istilah tersebut populer melalui tangan James Harvey Robinson (Robinson, 2002, pp. 1-12) dalam buku berjudul The New History. Menurutnya sejarah baru merupakan respons terhadap sejarah tradisional-konvensional, yang terlalu membatasi diri pada sejarah politik. Baginya, sejarawan baru harus memperluas pokok- 
pokok kajiannya dengan menggunakan semua penemuan yang telah dibuat mengenai kemanusiaan oleh para pakar antropologi, ekonomi, psikologi, dan sosiologi Artinya dalam konteks penulisan sejarah Islam dibutuhkan pendekatan-pendekatan lain yang lebih luas.

Sejarah baru ini bisa disebut juga dengan sejarah sosial. Kuntowijoyo memandang sejarah sosial yang dikembangkan oleh mazhab Annales Perancis adalah kajian tentang pelbagai peristiwa sejarah dengan menggunakan teori dan konsepkonsep ilmu sosial. Dengan metode ini, sejarawan mampu menerangkan pelbagai peristiwa dengan lebih jelas, sekalipun terkadang masih terikat pada model teoritisnya (Kuntowijiyo, 2003).

Sejarah baru juga disebut sejarah ilmiah (scientific history), karena bersifat lebih elaboratif dengan pendekatan-pendekatan yang relevan. Tampaknya penggunaan banyak sudut pandang dalam melihat sejarah inilah yang membuatnya lebih ilmiah dan objektif. Selain itu, karena pembahasannya mencakup semua dimensi kehidupan manusia pada masa lalu, ia juga disebut dengan sejarah total (total history atau integral history). Di sisi lain, karena sejarah baru dekat dengan problema dan banyak segi sosial yang dikaji, ia juga disebut sebagai sejarah multidimensional, dengan ruang cakup yang luas, di mana segala aspek pengalaman manusia di masa lalu menjadi objek kajian (Syamsudin, 2007, p. 307).

Hal di atas berbeda dengan Michael Foucault yang justru memberikan kritik terhadap konsep total history (Bed Lord, 2006, pp. 1-14). Ia mempunyai dua konsep yaitu konsep total history dan general history. Ia menulis, "the project of total history is one that seeks to reconstitute the overall form of civilization, the principle --material or spiritual--of society, the significance common to all the phenomena of a periode, the law that accounts for their cohesion-wha is called metaphorically the face of a periode." (Foucault, 1972, p. 16). Menurutnya, sejarah total lebih cenderung hanya mendeskripsikan sejarah secara menyeluruh menyangkut segala aspek yang terdapat pada suatu periode sejarah. Ini berbeda dengan konsep general history, yang ia sebut sebagai,"a geographical way of looking at the world in which one sees only 'space of dispersion', space where things proliferate in a jumbled-up manner on the same level one another"(Philo, 2000, p. 207). Konsep ini sangat dekat dengan konsep geneologi yang ditawarkannya. Baginya, general history mendorong orang untuk fokus pada aspekaspek spesifik suatu sejarah dengan mengkaji akar perkembangan suatu peristiwa. Ia menyebut total history terlalu mengabaikan hal-hal yang detail, spesifik, dan perbedaan-perbedaan di suatu tempat dan waktu.

Artikel ini menggunakan pendekatan total history yang dipadukan dengan pandangan general history dari Foucault. Bagi penulis, keduanya dapat digunakan dalam penulisan sejarah Islam. Total history ditujukan untuk memotret sejarah Islam secara keseluruhan, tidak parsial. Adapun general history dari Foucault digunakan untuk melakukan perincian secara spesifik terhadap peristiwa-peristiwa tertentu dalam sejarah Islam. Pendekatan ini berguna untuk mengupas dan menggali makna (meanings) suatu peristiwa yang sedang terjadi. Pertanyaan tentang mengapa suatu peristiwa terjadi, di mana peristiwa itu terjadi, dan apa kondisi yang 
melatarbelakanginya adalah di antara pertanyaan yang muncul dalam konteks general history.

Dengan menggunakan penelitian kualitatif berbasis studi pustaka (library research) artikel ini akan menjawab pertanyaan bagaimana seharusnya sejarah Islam dikonstruksi sehingga menghasilkan bangunan sejarah yang utuh dalam Islam? Jawaban atas pertanyaan ini diharapkan dapat berkontribusi bagi konsep penulisan sejarah Islam.

\section{HASIL DAN PEMBAHASAN}

Berikut ini merupakan deskripsi tentang sejarah politik Islam sejak periode Nabi Muhammad hingga periode modern. Ini ditujukan untuk melihat sejauhmana materimateri politik tertulis dalam buku-buku sejarah Islam.

\section{Potret Dominasi Politik dalam Penulisan Sejarah Islam}

\section{Politik Islam pada Periode Nabi}

Kekuasaan politik Islam dimulai dari proses perpindahan dari Makkah ke Yathrib yang kemudian dikenal dengan Madinah. Masyarakat Yatsrib waktu itu terdiri dari berbagai etnis, suku, dan agama. Di antara mereka terjadi konflik berkepanjangan, misalnya konflik antara suku Aus, Khazraj, dan Yahudi dengan segala klannya. Dalam pada itu, belum ditemukan pemimpin yang bisa mendamaikan mereka.

Untuk itulah sekelompok orang Yatsrib, 'Aus, dan Khazraj menemui beliau di Makkah pada tahun 621 M., dan menyatakan masuk Islam. Mereka berjanji tidak menyembah selain Allah dan meninggalkan perbuatan jahat serta akan mentaati Rasulullah SAW. Peristiwa ini disebut Bai'at al-'Aqabah al-Ula. Sosok pribadi Muhammad SAW menarik perhatian mereka untuk dijadikan tumpuan sebagai pemimpin.

Pada tahun $622 \mathrm{M}$ terjadi bai'at yang ke dua. Isinya, mereka berjanji akan melindungi Nabi sebagaimana melindungi keluarga mereka dan akan mentaati beliau sebagai pemimpin mereka. Sementara itu, Nabi berjanji akan berjuang bersama mereka, baik dalam perang maupun damai (Hisyam, 2001; Ishaq, 2004). Kendati demikian, pembentukan pemerintahan tidak termasuk dalam tugas yang diwahyukan kepadanya (Raziq, 1995), tetapi tidak diragukan lagi bahwa Nabi dalam kariernya mengemban risalah Islam selalu berada dalam percaturan politik, misalnya mengadakan kontak dengan negara kerajaan lain, mempersiapkan pasukan perang, dan memberlakukan peraturan untuk kerukunan orang banyak.

Dengan demikian keberadaan Nabi sebagai pemimpin masyarakat Madinah yang oleh banyak sejarawan disebut sebagai kepala negara melalui proses penunjukan dan kesepakatan orang banyak. Seolah ketika itu ada penyerahan kekuasaan diri dari peserta bai'at kepada Nabi yang diakui sebagai pemimpin mereka. Dalam ilmu politik proses ini disebut kontrak sosial (Sabine, 2000, p. 398).

\section{Politik Islam setelah Masa Nabi}


Pada bagian ini penulis hanya fokus memotret perpindahan kekuasaan dari satu masa ke masa lainnya, yaitu melihat sejarah Islam berdasarkan periode politik kekuasaan. Secara periode politik, Harun Nasution (2005) dengan terang menggunakan terminologi sejarah Islam untuk menyebut tiga periode utama kekuasaan politik Islam sebagai sejarah dominan. Tiga periode itu adalah pertama, periode klasik (650-1250 M), yang terbagi ke dalam dua masa yaitu: 1) masa kemajuan Islam I (650-1000 M). Pada periode ini hidup para Khulaf al-Rashidin, Bani Umayah, dan Bani Abbas; 2) masa disiintegrasi: (1000-1250 M). Kedua, periode pertengahan (1250-1800 M), yang terbagi ke dalam dua masa yaitu: 1) masa kemunduran I (1250-1500 M); 2) Masa tiga kerajaan besar (1500-18oo M), yaitu Kerajaan Usmani atau Turki Usmani, Kerajaan Safawi di Persia, dan Kerajaan Mughal di India. Masing-masing tiga Kerajaan Besar ini juga mengalami fase kemajuan (1500-170o M) dan fase kemunduran II (1700-180o M). Ketiga, periode modern (180o M).

\section{Kekuasaan Islam Periode Klasik: dari Masa Sahabat, Bani Umayah, hingga Bani Abbas}

Persoalan yang pertama muncul ketika Rasulullah wafat adalah siapa yang menggantikan beliau sebagai pemimpin umat atau kepala negara. Apakah dengan cara pemilihan langsung atau melalui perwakilan atau bagaimana, di masa hayatnya beliau tidak menyebut ini, dan tidak ada satu ayat al-Quran pun berbicara tentang suksesi ini. Setelah melalui perdebatan sengit antara kaum Anshar dengan kaum Muhajirin, nyaris terjadi perpecahan umat, akhirnya dapat diperoleh kesepakatan, Abu Bakar menggantikan Rasulullah, dengan sebutan Khalifah (al-Thabari, 2005, p. 38-41). Pengangkatan Abu Bakar sebagai kepala negara ini bukan karena ia mempunyai hubungan famili dengan Nabi atau mertua, tetapi karena potensi pribadinya yang dilambangkan dengan penunjukan Nabi kepadanya untuk menggantikan imam dalam shalat ketika Nabi sakit (Zaidan, 2000, p. 59).

Berbeda dengan ini adalah proses pengangkatan Umar bin al-Khatthab yang menggantikan Abu Bakar. Beberapa saat sebelum meninggal, Abu Bakar mencoba mencari tahu secara diam-diam, siapa yang pantas menggantikannya. Ia tidak mau meninggalkan rakyat terperangkap dalam konflik karena suksesi (Zahrah, t.t, p. 95). Akhirnya ia memutuskan berwasiat kepada umat agar sepeninggalnya kelak, Umar bin al-Khattab-lah yang dibait menggantikannya. Dengan cara ini, terdapat semacam pengangkatan putera mahkota, masyarakat tidak perlu bingung mencari pengganti khalifah, seperti yang terjadi ketika Rasulullah wafat. Umar dikenal sebagai pemimpin yang tegas dan lugas tetapi dekat dengan masyarakat.

Lain lagi kebijakan yang diambil oleh Umar menjelang wafatnya. Ia tidak mengangkat "putra mahkota," tetapi dalam wasiatnya ia menunjuk enam orang tokoh untuk menetapkan khalifah yang menggantikannya. Boleh jadi, sekarang disebut mengangkat formatur. Satu di antara enam orang adalah Abdullah ibn Umar yang menurut Umar, tokoh ini boleh bersuara, tetapi tidak boleh dipilih. Ia tidak mau berlaku nepotisme.

Akhirnya Usman bin Affan terpilih dan dibai'at sebagai khalifah. Kalau Umar terkenal anti nepotisme, ditunjukkan dengan pesannya menjelang ia wafat agar Abdullah anaknya tidak diangkat menjadi penggantinya, maka Usman menghidupkan 
nepotisme dengan mengangkat para pejabat daerah dari keluarganya. Pergantian Usman ke Ali bin Abu Thalib disebabkan oleh karena Usman terbunuh oleh pemberontak dari kalangan umat Islam. Terpilihnya Ali ini atas desakan mayoritas masyarakat Islam di Madinah dan sekitarnya agar tidak ada kekosongan kekhalifahan. Pengangkatan ini tidak melalui proses pertemuan seluruh sahabat senior karena di samping waktunya mendesak, mereka berada di wilayah yang jauh dari Madinah, pusat pemerintahan.

Empat orang khalifah ini dalam sejarah disebut al-Khulafa' al-Rashidun. Pengangkatan empat khalifah tersebut terjadi dengan cara yang berlainan satu dengan yang lain, dan tidak menggunakan cara suksesi yang mentradisi di kerajaan. Abu Bakar diangkat dengan pemungutan suara, Umar dengan pengangkatan putera mahkota, Usman dengan fomatur, dan Ali dengan pemungutan suara lagi. Philip K. Hitti (2008, p. 183) menilai pemerintahan keempat tokoh ini sebagai periode pemerintahan Republik.

Setelah masa sahabat, kekhalifahan dipegang oleh keluarga Umayyah secara turun temurun hingga runtuhnya pada tahun $750 \mathrm{M}$. Dinasti ini didirikan oleh Muawiyah bin Abu Sufyan, dengan ibukota negara di Damaskus. Daerah-daerah yang dikuasai Islam di zaman Dinasti ini adalah Spanyol, Afrika Utara, Suria, Palestina, Semenanjung Arabia, Irak, sebagian dari Asia Kecil, Persia, Afghanistan, daerah yang sekarang disebut Pakistan, Rurkmenia, Uzbek, dan Kirgis (di Asia Tengah) (Nasution, 2005, p. 52).

Di samping perluasan wilayah kekuasaan, masa Bani Umayah ditandai pula dengan pengembangan kebudayaan Arab (Hasan, t.t, p. 378). Salah satunya ialah dengan mengubah bahasa administrasi dari bahasa Yunani dan Pahlawi ke bahasa Arab. Dinasti ini juga mengubah mata uang di daerah-daerah yang dikuasai Islam (Zaidan, 2000, p. 85). Pengembangan bahasa Arab pada masa ini sangat diperhatikan. Selain itu juga perhatian kepada tafsir, hadis, fikih, dan ilmu kalam. Adapun yang menjadi pusat kegiatan ilmiah ini adalah Kufah dan Basrah di Irak (Amin, 200o, p. 21).

Setelah keruntuhannya, kekhalifahan berpindah ke tangan keluarga Abbasiyah yang didirikan oleh Abdullah al-Saffah bin Muhammad bin Ali bin Abdullah al-'Abbas, dengan ibukotanya Bagdad mulai tahun 750 sampai dengan $1258 \mathrm{M}$. Kendati didirikan oleh Abu al-'Abbas namun pembina sebenarnya adalah Abu Ja'far al-Mansur.

Berbeda dengan Bani Umayah yang banyak berfokus pada ekspansi daerah kekuasaan Islam, masa Bani Abbas lebih concern pada pembentukan dan perkembangan kebudayaan dan peradaban Islam. Pada masa ini perhatian kepada filsafat Yunani memuncak. Selain filsafat juga berkembang ilmu kedokteran, sastra, matematika, optika, geografi, kimia, fisika, astronomi, dan sejarah (Amin, 20oo, p. 207).

Pada masa Dinasti ini, kehidupan perekonomian meningkat. Pertanian ditingkatkan dengan mengadakan irigasi, yang menghasilkan gandum, beras, korma, dan zaitun. Hasil pertambangan seperti emas, perak, dan tembaga juga berkembang. Selain itu pendirian rumah sakit, pendidikan kedokteran, dan farmasi dibangun. Pemandian-pemandian umum juga didirikan (Nasution, 2005, p. 58). 
Di masa ini juga terjadi kontak pertama kalinya Islam dengan kebudayaan Barat, atau tegasnya dengan kebudayaan Yunani Klasik yang terdapat di Mesir, Suria, Mesopatamia, dan Persia. Menurut Ahmad Amin (2000), pertemuan Islam dengan peradaban Persia memberikan warna tersendiri bagi perkembangan kegiatan keilmuan dalam Islam, namun para cendikiawan Islam pada masa itu bukan hanya menguasai ilmu pengetahuan dan filsafat dari buku-buku Yunani itu, tapi juga melakukan penyelidikan-penyelidikan sendiri.

Masa Tiga Kerajaan Besar (Kerajaan Usmani di Turki, Kerajaan Safawi di Persia, dan Kerajaan Mughal di India)

Setelah Baghdad jatuh, memasuki abad 14, melalui proses panjang pemerintahan Islam berpindah ke Turki hingga awal abad 20. Pada masa kerajaan Usmani daerahdaerah kekuasaan meliputi: Asia Kecil, Armenia, Irak, Suria, Hejaz serta Yaman di Asia, Mesir, Libia, Tunis serta al-Jazair di Afrika dan Bulgaria, Yunani, Yugoslavia, Albania, Hongaria, dan Rumania di Eropa (Nasution, 2005, p. 84).

Di tengah-tengah membesarnya Turki terdapat kerajaan besar Islam lainnya. Kerajaan Safawi di Persia. Kerajaan ini berasal dari Syeikh Ishak Safiudin dari Ardabil di Azarbaijan. Kerajaan ini menguasai seluruh wilayah Persia. Di sebelah Barat berbatasan dengan Kerajaan Usmani dan di sebelah Timur berbatasan dengan India yang pada waktu itu berada di bawah kerajaan Mughal. Syah Ismail Safawi membuat aliran Syi'ah sebagai Mazhab yang dianut negara (Nasution, 2005, p. 81).

Selain itu, terdapat pula kerajaan Mughal di India dengan Delhi sebagai Ibu Kota. Kerajaan ini didirikan oleh Zahiruddin Babur (1482-1530 M). Kerajaan ini menguasai Kabul, Lahore, sehingga menguasai India Tengah waktu itu. Pada masa ini juga terjadi penggabungan antara Malwa dan Gujarat ke daerah-daerah kekuasaan Kerajaan Mughal (Nasution, 2005, p. 81).

Masing-masing tiga kerajaan ini memiliki masa kejayaannya sendiri terutama dalam bentuk literatur dan arsitek. Muncul literatur dalam bahasa Turki, Urdu, Persia, selain bahasa Arab. Bahkan keberadaan bahasa Arab menurun. Dalam bidang arsitek, masjid-masjid berkembang seperti di Turki terdapat Masjid yang terkenal, Aya Sofia yang pada mulanya Geraja tetapi diubah menjadi Masjid (Hitti, p.715). Di India terdapat Taj Mahal di Agra. Begitu juga di Persia, terdapat Masjid Besar Isfahan yang dibangun untuk Syah Abbas (Yatim, p. 145; Hodgson, 1981, p. 40).

Dengan format kerajaan ini maka sistem suksesi adalah seperti yang terjadi di kerajaan pada umumnya, tidak seperti yang terjadi di masa Khulafa al-Rasyidun. Selama berlangsung budaya kerajaan, tidak ada pikiran pembatasan periode jabatan. Bila ada yang tidak sabar, maka pergantian kekuasaan melalui perang saudara.

\section{Periode Modern: Ke Arah Nasionalisme}

Pada abad 19, ketika pengaruh Barat terhadap sistem pemerintahan di Turki Usmani semakin kuat, dunia politik Islam mulia diwarnai ketegangan. Pikiran menyelenggarakan pemerintahan negara nasional mulai tersosialisasikan di 
pemerintahan Utsmani, ditandai dengan lahirnya Tanzimat dan konstitusi di bawah kepeloporan kelompok Utsmani Muda.

Pemikiran semacam itu terasa ganjil bagi dunia Islam karena selama ini kekuasaan itu hanya dipilah menjadi Dar al-Islam dan Dar al-Harb. Pemilahan wilayah kekuasaan tersebut didasarkan hubungan keagamaan, bukan hubungan kebangsaan, sehingga yang dimaksud Dar al-Islam adalah satu kekuasaan politik.

Setelah Perang Dunia I dan II, dunia Islam menemukan iklim lain. Masyarakat Islam mendirikan negara-negara nasional, negara yang didasarkan kebangsaan dan teritorial. Ada yang mengambil bentuk kerajaan dan ada yang republik (Robinson, 2010). Corak negara dan pemerintahan setelah era demokrasi, semenjak Revolusi Perancis, berdampak kepada kesadaran baru di dunia Islam, bahwa loyalitas tidak harus kepada khalifah, yang cakupan wilayah spiritualnya seantero dunia, tetapi kepada negara dan pemerintahan kebangsaan yang teritorialnya lebih konkret. Karena kesadaran ini menimbulkan dampak lain, yaitu terjadinya perpecahan, setidaknya kekurang-pedulian sesama muslim akibat perbedaan kesukuan dan kebangsaan, maka muncul ide mengembalikan kekhalifahan agar dapat mengikat dunia Islam kendati format negara nasional tetap berjalan.

\section{Kritik atas Konstruksi Penulisan Sejarah Politik Islam}

Paparan di atas menggambarkan bagaimana kajian-kajian sejarah Islam dominan lebih banyak diwarnai dengan uraian mengenai empat kawasan, yaitu kawasan pengaruh kebudayaan Arab (Timur Tengah dan Afrika Utara, termasuk Spanyol Islam), kawasan pengaruh kebudayaan Persia (Iran dan negara-negara Islam Asia Tengah), kawasan pengaruh kebudayaan Turki, dan kawasan pengaruh kebudayaan India-Islam (Yatim, 2014, p. 5). Hal ini tampaknya sangat ditentukan oleh perkembangan politik Islam sampai periode pertengahan.

Sebagai kritik atas periodisasi kekuasaan politik dalam Islam, Ahmad Amin (2000) menyatakan bahwa sejatinya tidaklah benar ketika satu periode kekuasaan Islam diganti dengan kekuasaan Islam lain dianggap sebagai sesuatu yang terpisah-pisah (fashilah/munfashilah). Bagi Amin, satu kekuasaan dengan kekuasaan lain berada dalam kesinambungan sejarah. Sejarah itu tidak pernah terputus (Amin, 2000, p. 21). Dengan demikian, dominasi satu kekuasaan Islam atas kekuasaan Islam lain yang berujung pada orientasi politik semata dapat dihindari. Hal ini juga merupakan upaya meminimilisir anggapan miring mengenai Islam yang disebarkan dengan perang dan pedang.

Untuk upaya itu penulisan sejarah utuh (total history) sangat diperlukan. Foucault mendefinisikan total history sebagai upaya menyusun kembali secara keseluruhan bentuk peradaban, prinsip/dasar-dasar suatu masyarakat baik material maupun spiritual, kebiasaan yang siginifikan menyangkut segala fenomena suatu periode, hukum yang mengatur keterpaduan mereka, atau apa yang disebut dengan wajah suatu periode (the face of the periode) (Philo, 2010; Kramsch, 2012). Konsep total history ini menemukan rumusannya secara tegas dan jelas dalam konsep The New History (Robenson, 2002), yaitu suatu kritik atas penulisan sejarah tradisional yang 
cenderung lebih didominasi politik, dan kedatangan The New History memberikan rumusan tentang penulisan sejarah secara utuh.

Dengan kerangka ini dapat ditegaskan bahwa sejarah utuh Umat Islam adalah sejarah kehidupan yang menggali dan memuat wajah kehidupan sosial Islam dari masa ke masa, dari aspek intelektual, tradisi pendidikan, kebudayaan, seni, arsitektur, mata pencaharian, pola interaksi kemasyarakatan, tradisi keberagamaan, pola keorganisasian sosial, termasuk juga tradisi hubungan sosial-keagamaan dengan pemeluk agama lain.

Dalam konteks periode sejarah politik pada bagian terdahulu, penulis sejarah Islam bisa mengeksplorasi secara lebih jauh sejarah sistem perekonomian pada masa Bani Umayah, sejarah pendidikan pada masa Bani Abasiyah (Amin, 20oo, pp. 51-52), atau sejarah arsitektur yang berkembang pada masa tiga kerajaan Besar. Semuanya bisa dikaji secara utuh dalam sebuah kajian khusus.

\section{Eksplorasi Potensi Sejarah Non-Politik}

Beberapa contoh sejarah sosial dalam Islam misalnya dapat dilihat dalam sejarah pendidikan madrasah. Salah satu madrasah yang terkenal dalam Islam adalah Madrasah Nizamiyah. Di antara pelajaran yang diajarkan di madrasah ini adalah teologi, hukum Islam, filsafat, logika, sufisme dan ilmu-ilmu alam, di samping tafsir, hadis, sejarah Islam dan sebagainya (Nasution, 2005, pp. 110-111). Tentang pendidikan tinggi dibentuk juga lembaga-lembaga lain seperti Bait al-Hikmah yang didirikan oleh Khalifah alMakmun di tahun 830 M. Atau di Cardova misalnya, Abd al-Rahman III mendirikan Universitas Cardova yang dikunjungi mahasiswa Islam dan Kristen.

Selain madrasah dan masjid, perpustakaan juga merupakan tempat mencari ilmu pengetahuan. Di dalamnya tidak hanya menyediakan buku-buku agama, tapi juga pengetahuan non-agama seperti filsafat, logika, astronomi, matematika, dan ilmu-ilmu lain. Di perpustakaan orang dapat membaca, menulis, dan berdiskusi (Zaidan, 2005, p. 144).

Dalam bidang pertanian misalnya, bisa berfokus pada bagaimana pertanian menghasilkan gandum, beras, korma, dan zaitun. Pertembangan menghasilkan perak, emas, tembaga, besi dan lain-lain. Ini terjadi pada masa Bani Abbasiyah (Nasution, 2005, p. 63). Terdapat banyak contoh sejarah sosial yang bisa diungkap tanpa harus menekankan nomenklatur politik sebuah kekuasaan.

Selama ini sejarah Islam terkesan parsial. Contoh yang cukup gamblang berkaitan dengan ini adalah menyangkut sejarah Hijaz. Sisi lain Hijaz sebagai kawasan sentral bagi transmisi Islam di dunia hampir saja luput dari perhatian (untuk tidak mengatakan tidak sama sekali). Hijaz merupakan negeri kelahiran Islam, dan sering disebut sebagai pusat kegiatan keagamaan agama Islam.

Dari perspektif sejarah perpolitikan, Mekah dan Madinah yang berada di kawasan Hijaz dan terkenal sebagai kota suci umat Islam ini memiliki dinamikanya tersendiri. Setelah kekuasaan politik berpindah dari al-Khulafa al-Rasyidin ke tangan Bani Umayah, Hijaz tidak lagi menjadi basis kekuasaan politik. Kekuasaan politik Islam pindah ke Damaskus sebagai ibu kota Bani Ummayah, dan selanjutnya kekuasaan Islam 
pindah ke tangan Bani Abbasiah di Baghdad. Hijaz bagaikan negeri terlupakan dan setelah keruntuhan Bani Abbasiah seluruh wilayah Arab berada di bawah kekuasaan politik non Arab.

Kekuasaan Turki Usmani yang menjadikan Mesir sebagai salah satu provinsinya ketika itu dianggap oleh penguasa Hijaz sebagai pewaris kepemimpinan Islam. Walaupun kemudian dalam perkembangannya ada rasa kekecewaan terhadap kekuasaan Turki itu sendiri sebagai akibat dari kebijakan-kebijakan politik Turki Usmani dan akhirnya negeri-negeri yang berada di wilayah kekuasaan Turki menuntut untuk merdeka. Setelah Turki kalah dalam Perang Dunia I negeri-negeri yang dulu berada pada kekuasaan Turki kini jatuh ke tangan Barat.

Demikian dinamika posisi Hijaz dalam konteks kekuasaan-politik. Namun berbeda dengan posisi sentralnya dalam ranah sosial Umat Islam. Kalau boleh dikatakan, kawasan ini tetap produktif sebagai sebuah kawasan yang menjadi pusat strategis bagi aktivitas sosial-pendidikan Islam. Tampaknya para sejarawan seakan tidak melihat kawasan ini sebagai suatu objek sejarah yang penting untuk dilirik. Para sejarawan sendirilah yang menjadikan sejarah kawasan ini termarjinalkan. Selama ini, sejarah Timur Tengah yang didominasi oleh pembicaraan mengenai kekuatan politik, menjadikan kawasan-kawasan seperti Damaskus, Baghdad, Kairo atau Istambul sebagai basis kekuatan politik Islam. Sedangkan sejarah Hijaz kurang disinggung dalam kancah sejarah politik Islam. Kawasan ini hanya dianggap sebagai sejarah kota-kota pusat ibadah dan keagamaan, khususnya ibadah Haji, padahal jika hendak ditelusuri lebih jauh, kawasan ini, khususnya Mekah dan Madinah (al-Haramayn) merupakan dua kota yang bukan saja kota ibadah. Akan tetapi juga sebagai kota yang sangat strategis dan berperang penting bagi perkembangan Islam di dunia, terutama di Indonesia.

Azyumardi Azra melalui disertasinya berjudul "The Transmission of Islamic Reformism to Indonesia: Network of Midlle Eastern and Malay-Indonesian 'Ulama in the Seventeenth and Eighteenth Centuries" cukup berhasil memaparkan posisi sentral kawasan Haramayn ini sebagai pusat jaringan kaderisasi Ulama, khususnya ke Nusantara (Indonesia). Azra (2016) melihat bagaimana orang dari berbagai negara belajar menuntut Ilmu di kawasan ini. Di sana terdapat banyak para Guru, Ribat atau halaqah atau Madrasah yang mengajarkan ilmu-ilmu agama. Dari kawasan ini para pelajar ilmu agama kembali ke tanah air masing-masing untuk menyebarkan Islam. Kontribusi utama dari karya Azra ini adalah kehadirannya sebagai sebuah kajian sejarah Islam dari aspek intelektual. Ia melihat itu sebagai sebuah sejarah sosial-intelektual Islam (Azra, 2016).

Selain itu, konteks sejarah Islam secara total pada prinsipnya bisa pula berdasarkan konsep peradaban Islam (Islamic civilization) itu sendiri. Peradaban dalam bahasa Arab dikenal dengan 'al-hadharah', sedangkan dalam bahasa Inggris disebut dengan civilization. Terdapat pula pandangan yang menyamakan peradaban dengan kebudayaan (Zaidan, 200o). Jadi peradaban Islam juga kebudayaan Islam itu sendiri, namun dalam perkembangannya, dua istilah tersebut dibedakan.

Kebudayaan lebih merupakan bentuk ungkapan tentang semangat mendalam suatu masyarakat, sedangkan manifestasi-manisestasi kemajuan mekanis dan 
teknologis lebih berkaitan dengan peradaban. Jika kebudayaan lebih banyak direfleksikan dalam seni, sastra, religi (agama), dan moral, maka peradaban terefleksi dalam politik, ekonomi dan teknologi (Yatim, 2014; al-Sharqawi, 1986). Jadi pendekatan total history (sejarah utuh) yang dikemukakan dalam artikel ini merujuk pada segala aspek peradaban dan kebudayaan itu dalam sebuah periode sejarah Islam.

Dengan kacamata tersebut dapat dikatakan bahwa di dunia ini terdapat banyak peradaban-peradaban Islam. Pembicaraan tentang sejarah Islam tidak lagi berkutat pada sejarah kawasan Islam yang bertendensi politik seperti yang disebutkan di atas. Dari sini pula sejarah Islam Nusantara atau lebih luas sejarah Islam Asia Tenggara menemukan ruangnya sendiri. Apa yang disebut dengan Islam Nusantara merupakan upaya menampilkan sejarah Islam Nusantara yang unik baik politik maupun sosialnya. Dalam konteks Indonesia terdapat buku-buku yang memaparkan tentang sejarah Islam di Indonesia seperti di antaranya karya Buya Hamka, Sejarah Umat Islam Jilid IV, karya Taufiq Abdullah berjudul Sejarah Umat Islam Indonesia. Hamka membagi sejarah Islam Indonesia menjadi tujuh periode. Sedangkan Taufiq Abdullah membagi sejarah Islam Indonesia menjadi delapan periode (Yatim, 2015, p. 6-7).

Masing-masing sejarah tentu memiliki kekhasan tersendiri. Sejarah Islam untuk kawasan-kawasan seperti yang terpapar dalam narasi umum sejarah Islam tentulah tidak sama dengan sejarah Islam di Asia Tenggara atau di Indonesia. Karenanya, ketika membicarakan sejarah Islam Indonesia, tentu sebenarnya yang diharapkan bukan hanya sejarah yang berkutat periode kekuasaan politik dan penaklukan terhadap wilayah-wilayah tertentu, namun lebih penting dari sekadar itu adalah bagaimana menggambarkan sejarah sosial dan kehidupan Umat Islam secara menyeluruh.

Satu alasan mungkin dapat diajukan mengapa terminologi politik selalu menjadi acuan dalam penentuan sejarah Islam. Hal itu karena memang tidak bisa dipungkiri bahwa sejarah peradaban Islam yang panjang dan luas itu tidak bisa dilepaskan dari pembahasan sejarah politik. Bukan saja karena politik sangat menentukan perkembangan aspek-aspek peradaban tertentu, tetapi terutama karena sistem politik dan pemerintahan itu sendiri merupakan satu aspek penting dari peradaban (Yatim, 2014, p. 5-6).

\section{PENUTUP}

Dari pembahasan di atas jelas bahwa penulisan sejarah Islam lebih cenderung diwarnai aspek politik, sedangkan aspek sosial tidak banyak dibicarakan. Agaknya seperti terpapar di atas, salah satu faktor yang memengaruhinya adalah karena orang (dalam hal ini para sejarawan) menilai kekuasaan politik sebagai titik sentral bagi peradaban suatu bangsa. Islam seperti dinilai oleh Harun Nasution bisa berkembang karena kekuasaan politik berada di tangan Rasulullah SAW.

Karena itu, elaborasi dan penggalian mengenai sejarah Islam secara utuh sangat penting adanya. Caranya ialah dengan tidak mengkategorikan sejarah Islam berdasarkan periode perpindahan kekuasaan politik dari dinasti ke dinasti lain, sementara melupakan pendalaman terhadap aspek sosial ekonomi, pendidikan, kebudayaan, seni, arsitektur, pola interaksi dan pola kehidupan masyarakat, mata pencaharian masyarakat, dan sebagainya. 
Sebagai rekomendasi, sebaiknya penulisan sejarah politik dan sosial dalam Islam harus dipisahkan. Terdapat banyak aspek yang bisa dibahas dalam kaitannya dengan kehidupan sosial umat Islam, seperti yang penulis paparkan di atas.

\section{REFERENSI}

Abu Zahrah, Muhammad. (t.t). Tarikh al-Mazhahib al-Islamiyah fi al-Siyasah wa al'Aqidah. Beirut: Dar al-Fikr.

Al-Sharqawi, Effat. (1986). Filsafat Kebudayaan Islam. Bandung: Penerbit Pustaka.

Al-Thabari. (2005). Tarikh al-Umam wa al-Muluk. Beirut: Dar al-Kutub al-'Ilmiyah. 2005. Juz IV, versi PDF.

Amin, Ahmad. (2000). Dhuha al-Islam. Kairo: Lajnah al-Ta'lif wa al-Nasyr.

Foucault, Michel. (1972). The Archeology of Knowledge and The Discourse of Language, diterjemahkan oleh A.M. Sheridan Smith. New York: Pantheon Books.

Haghnavaz, Javad. (2013). A Brief History of Islam (The Spread of Islam). International Journal of Business and Social Science. 4(17), 1-5.

Hasan, Ibrahim Hasan. (1996). Tarikh al-Islam: al-Siyasi wa al-Dini wa al-Thaqafi wa alIjtima’i. Kairo: Maktabah al-Nahdhah al-Mishriyyah.

Hitti, Philip K. (2008). History of the Arabs. New York: The Macmillan Press Ltd.

Hodgson, Marshal G.S. (2002). The Venture of Islam. Chicago: The University of Chicago Press.

Huppert, George. (1982). "Lucien Febvre and March Bloch: The Creation of the Annales." The French Review. 55(4), 510-513.

Ibn Hisyam. (2001). Al-Sirah al-Nabawiyyah. Beirut: Dar Ihya al-'Arabi.

Ibn Ishaq. (2004). Sirah Rasul Allah, diterjemahkan oleh Alfred Guillaume. The Life of Muhammad. Oxford: Oxford University Press.

Kramsch, O.T. (2012). Michel Foucult: Personal Communication. Spatial Turn 1, Radboud University Nijmegen.

Kuntowijoyo. (2003). Metodologi Sejarah. Yogyakarta: Tiara Wacana.

Lord, Bed. (2006). "Foucault's Museum: Difference, Representation, and Geneology.” Museum and Society, 4(1), 1-14.

Nasution, Harun. (2005). Islam Ditinjau dari Berbagai Aspeknya. Jakarta: Penerbit Universitas Indonesia.

Philo, C. (200o). “Foucult's Geography”. M. Crang dan N. Thrift (eds). Thingking Space. London: Routledge.

Raziq, Ali Abd. (1995). Kekhilafahan dan Dasar-dasar Kekuasaan, dalam Islam dan Perubahan, diterjemahkan oleh Machnun Husein. Jakarta: Rajawali.

Robinson, Chase F. (Ed). (2010). The New Cambridge History of Islam Volume I: The Formation of the Islamic World Sixth to Eleventh Centuries. New York: Cambridge University Press. 
Robinson, James Harvey. (2002). The New History. New York: The Free Press.

Sabine, G. H. (2000). A History of Political Thought. New York: Collier Books.

Swoboda, Hannes dan Jan Marinus Wiersma (Eds.). (2009). Politics of The Past: The Use and Abuse of History. Socialits Group.

Syamsudin, Helius. (2007). Metodologi Sejarah. Yogyakarta: Ombak.

Yatim, Badri. (1999). Sejarah Sosial Keagamaan Tanah Suci Hijaz 180o-1925. Jakarta: Logos.

Yatim, Badri. (2002). Historiografi Islam Kontemporer, Wacana, Aktualitas, dan Aktor Sejarah. Jakarta: Gramedia Pustaka.

Yatim, Badri. (2014). Sejarah Paradaban Islam Dirasah Islamiyah II. Jakarta: PT. RajaGrafindo Persada.

Yatim, Badri. (2016). Jaringan Ulama Timur Tengah dan Kepulauan Nusantara Abad XVII dan XVIII. Bandung: Mizan.

Zaidan, Jurji. (200o). Tarikh al-Tamaddun al-Islami. Kairo: Dar al-Hilal. 